
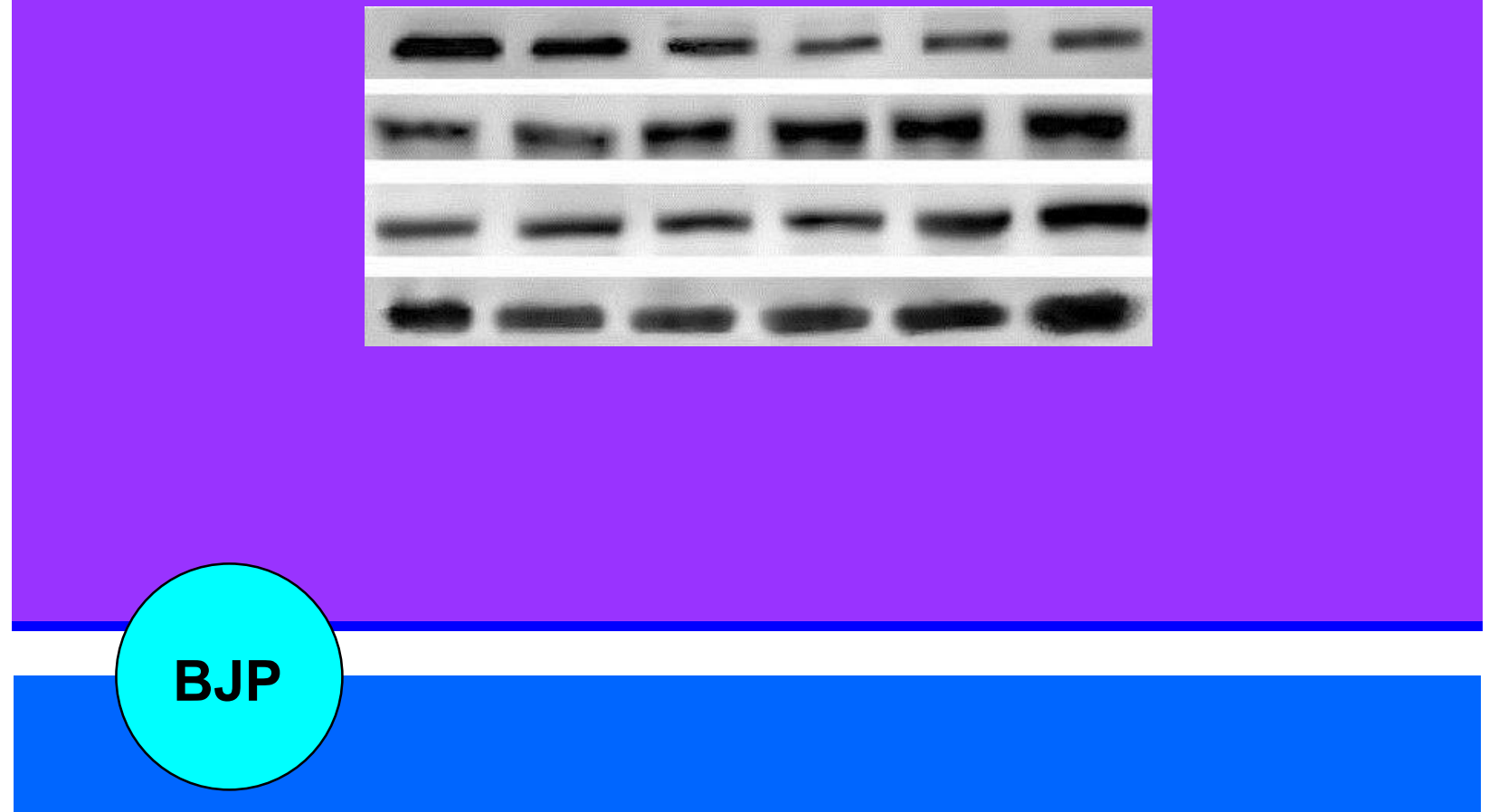

Bangladesh Journal of Pharmacology

Research Article

Ellagic acid regulates $W n t / \beta$-catenin signaling pathway and CDK8 in HCT 116 and HT 29 colon cancer cells 


\title{
Ellagic acid regulates Wnt/ $\beta$-catenin signaling pathway and CDK8 in HCT 116 and HT 29 colon cancer cells
}

\author{
Yang Fang1, Hong Zhou', Jian-Fu Xia' ${ }^{1}$, Jie-Jun Lin², Ri-Zeng Li', Da-Qing Yang1, \\ Mai-Yu Xu${ }^{3}$ and Xiao-Yang Li
}

${ }^{1}$ Department of Colorectal and Anus Surgery, Wenzhou Central Hospital, Zhejiang Province 325000, China;

${ }^{2}$ Department of Gastroenterology, Wenzhou Central Hospital, Zhejiang Province 325000, China; ${ }^{3}$ Department of Hepatobiliary Surgery, Wenzhou Central Hospital, Zhejiang Province 325000, China.

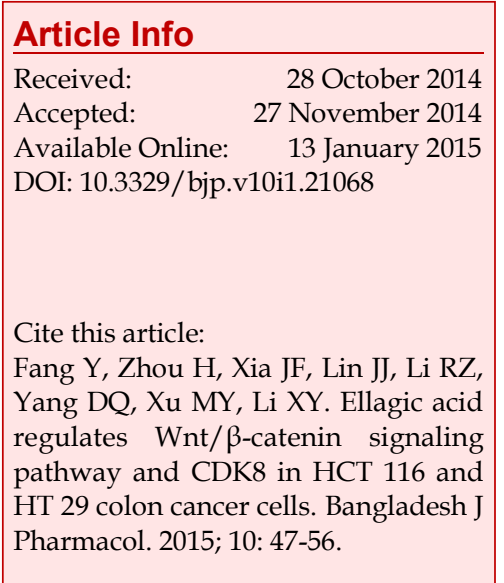

\section{Abstract}

Colorectal cancer is one of the leading causes of death worldwide. Wnt/ $\beta$ catenin signalling pathway plays a central role in normal cellular responses, making it a potent target in cancer therapy. Study was taken to assess whether ellagic acid modulates $\mathrm{Wnt} / \beta$-catenin pathway and CDK8 activity in colon cancer cells (HT 29 and HCT 116). Ellagic acid caused significant decrease in viability of cancer cells and markedly down-regulated the expression of CDK 8, $\beta$-catenin, survivin, c-Myc and cyclin D1. siCDK8 transfection resulted in marked reduction in the expression of survivin, c-Myc and cyclin D1 as well. Considerable up-regulation in the expression of p- $\beta$ catenin, axin1 and 2 following ellagic acid exposure were observed. Ellagic acid was able to effectively reduce cell viability and modulate expressions of Wnt/ $\beta$-catenin signalling cascade proteins and down regulate the activity and expression of CDK8 in HT 29 and HCT 116 cells.
\end{abstract}

\section{Introduction}

Colorectal cancer is the second most frequent malignancy and the second leading cause of death due to cancer globally (Walker et al., 2014). Colon cancer carcinogenesis has been reported to be associated with genetic errors in genes involved in apoptosis and cell proliferation (Davies et al., 2005; Watson, 2006; Damaschke et al., 2013; Bharati et al., 2014). Genetic defects triggering aberrant activation of $\mathrm{Wnt} / \beta$-catenin signalling are common and are reported in over $90 \%$ of sporadic cases of colon cancer (Miyaki et al., 1994; Clevers, 2006; Klaus and Birchmeier, 2008; Schon et al., 2014). The key effecttor of $W n t / \beta$-catenin signaling pathway is $\beta$-catenin that upon activation of Wnt signal, translocates into the nuclear region forming a ternary complex with transcription factors- TCF/Lef (T-cell factor, lymphoid enhancer factor) and activates genes involved in cell proliferation as c-Myc and Cyclin D1 (Reya and Clevers,
2005; Espada et al., 2009).

Cyclin-dependent kinase 8 (CDK8) is implicated in transcriptional regulation of key pathways involved in colon cancers such as Wnt/ $\beta$-catenin (Kim et al., 2006), Notch (Fryer et al., 2004) and p53 (Donner et al., 2007). The kinase activity of CDK8 is required for regulation of $\beta$-catenin dependent transcription and oncogenesis (Firestein et al., 2008; Morris et al., 2008). These observations suggest that therapeutic interventions targeting CDK8 and Wnt/ $\beta$-catenin signaling pathway is of clinical value.

Studies have demonstrated that phytochemicals are effective in modulating Wnt/ $\beta$-catenin signalling pathway (Zhang, et al., 2013; Kim et al., 2014). Ellagic acid, a dimeric derivative of gallic acid occurs naturally in fruits as- strawberry, raspberry, pomegranate, grapes and blackberries and in nuts (Thresiamma and Kuttan, 1996; Talcott and Lee, 2002; Mullen et al., 2003). Anti- 
oxidant, anticarcinogenic, and antiviral activities have been attributed to ellagic acid (Stoner and Gupta, 2001; $\mathrm{Xu}$ et al., 2003; Larrosa et al., 2006). The present study investigates the effectiveness of ellagic acid in regulating Wnt/ $\beta$-catenin signaling pathway and in modulating CDK8 kinase activity in HCT 116 and HT 29 colon cancer cells.

\section{Materials and Methods}

\section{Cell lines}

Human colon cancer cell lines - HT 29, and HCT116 were obtained from Sigma-Aldrich, St. Louis, MO, USA.

\section{Antibodies and reagents}

Ellagic acid was procured from Sigma-Aldrich, St. Louis, MO, USA. Mouse anti- $\beta$-catenin and mouse anti$\beta$-actin were purchased from BD Biosciences. Rabbit anti-p- $\beta$-catenin (S45) was from Cell Signaling Technology, Danvers, MA, USA. Rabbit - anti-axin1, anti-axin2, anti-survivin anti-cyclin D1, anti-c-Myc and anti-CDK8 were purchased from Sigma-Aldrich, St. Louis, MO, USA. All other chemicals used in the study were purchased from Sigma-Aldrich, St. Louis, MO, USA unless otherwise mentioned.

\section{Cell viability assay}

The cell viability assay was perfor-med as described previously (Pan et al., 2010; Zheng et al., 2010). The human colon cancer cells were seeded in 96-well microplates ( $2 \times 10^{5}$ cells / well). After the cells reached $70 \%$ confluence, the cells were treated with ellagic acid $(10,20,30,40$ and $50 \mu \mathrm{M})$ and $50 \mu \mathrm{M}, 5$-fluorouracil (5FU) as positive control for 72 hours. The final concentration of DMSO in culture medium was maintained at $0.05 \%$ (Jaramillo et al., 2010; Pan et al., 2010). Following 72 hours incubation, $10 \mu \mathrm{L}$ of MTT (5 $\mathrm{mg} / \mathrm{mL}$ ) in PBS was added to each well at a final concentration of $0.5 \mathrm{mg} / \mathrm{mL}$ and incubated for 4 hours. The supernatant was discarded and $100 \mu \mathrm{L}$ of a solution containing 10\% SDS ( $\mathrm{pH} 4.8), \mathrm{HCl}(0.01 \mathrm{M})$ and 5\% isobutyl alcohol was added to each well and mixed thoroughly to dissolve the formazan crystals. Cell viability was measured by reading the absorbance at 570 $\mathrm{nm}$ using an enzyme-linked immunosorbent assay (ELISA) reader (RT6000, Guangdong, China). Viability was expressed as a percentage of absorbance values in treated cells to that in control cells: cell viability $(\%)=$ $\mathrm{OD}_{\text {test }} / \mathrm{OD}_{\text {control }} \times 100 \%$.

\section{Western blotting}

The human colon cancer cells (HCT 116 and HT 29) were incubated with ellagic acid $\left(\begin{array}{lll}10 & -50 & \mu \mathrm{M}\end{array}\right)$ as described in cell viability assay. Total cell lysates following incubation with ellagic acid was prepared in
RIPA buffer (50 mM Tris- $\mathrm{HCl} \mathrm{pH}$ 8.0, $150 \mathrm{mM} \mathrm{NaCl}, 1 \%$ NP-40, 0.5\% sodium deoxycholate, $0.1 \%$ SDS). Protein concentration was determined and equal amount of the protein samples were subjected to 13\% SDS-PAGE. Separated proteins were transferred to PVDF membranes (Millipore, Bedford, MA, USA). After blocking for 1 hour at room temperature in $5 \%$ bovine serum albumin in PBS-Tween 20, membranes were probed overnight at $4 \mathrm{\circ} C$ with the following antibodies: mouse anti- $\beta$ catenin, mouse anti- $\beta$-actin, rabbit anti-p- $\beta$ catenin (S45), anti-axin1, anti-axin2, anti-survivin, anticyclinD1, anti-c-Myc and anti-CDK8. The membranes were incubated with corresponding secondary antibodies for 2 hours at room temperature, and later visualized with an enhanced chemiluminescence (ECL) detection kit (Lab Frontier, Suwon, Korea). The blots were analyzed by LAS4000 (Fuji Film Corp., Tokyo, Japan). Band intensity was measured using ImageJ software (National Institute of Health, USA).

\section{CDK8 siRNA transfection}

The cancer cells were seeded in 6 -well plate at $1.5 \times 10^{5}$ per well, cultured for 24 hours and then transfected with 20 pm siRNA (Santa Cruz Biotechnology, St. Louis Park, MN, USA) with $10 \mu \mathrm{L}$ lipofectamine 2000 (Invitrogen), and incubated for 24 hours at $37^{\circ} \mathrm{C}$ with ellagic acid. Cells were then rinsed with phosphate buffered saline, and then lysed and analysed for the expression of c-Myc, survivin and Cyclin D1 as described above by western blotting.

\section{Data analysis}

The obtained values were statistically ana-lysed using of SPSS software version 17.0. The values are represented as mean $\pm S D$, for three individual experiments. Values obtained at $\mathrm{p}<0.05$ are considered significant as determined by ANOVA (one-way analysis of variance).

\section{Results}

The anticancer effect of ellagic acid at 10-50 $\mu \mathrm{M}$ on colon cancer cell lines were assessed by measuring cell viability by MTT assay. Ellagic acid brought about a dose-dependent decrease in the viability of HCT 116 and HT 29 cells (Figure 1). Ellagic acid at $50 \mu \mathrm{M}$ caused significant $(\mathrm{p}<0.05)$ multi-fold suppression in cell viability percentage both in HCT 116 and HT 29 cells. At 10 $\mu \mathrm{M}$, the cell viability was observed to be $86.8 \%$ in HCT 116 and $90.2 \%$ in HT 29 that gradually decreased to $24.1 \%$ and $30.1 \%$ at $50 \mu \mathrm{M}$ in HCT 116 and HT 29, respectively.

The canonical Wnt signaling pathway has emerged as a critical regulator pathway of cell proliferation and differentiation (Reya and Clevers, 2005). Since $\beta$-Catenin is a key effector that determines the activity of 


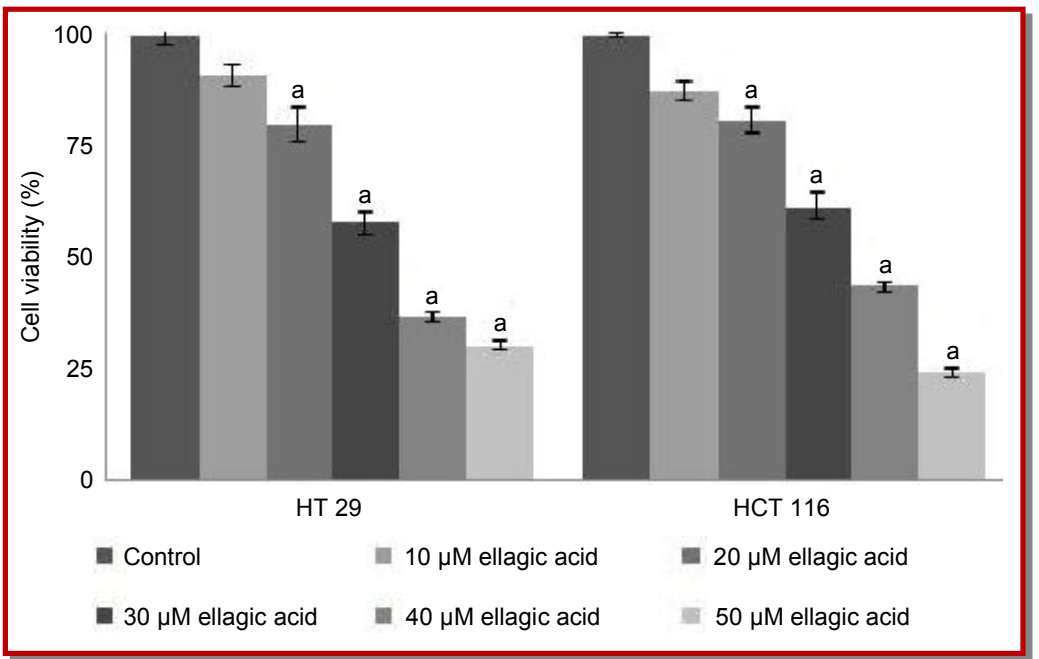

Figure 1: Effect of ellagic acid on the cell viability of colon cancer cells

Values are represented as mean $\pm \mathrm{SD}$; $\mathrm{n}=3$; arepresents $\mathrm{p}<0.05$ compared with control as determined by one-way ANOVA

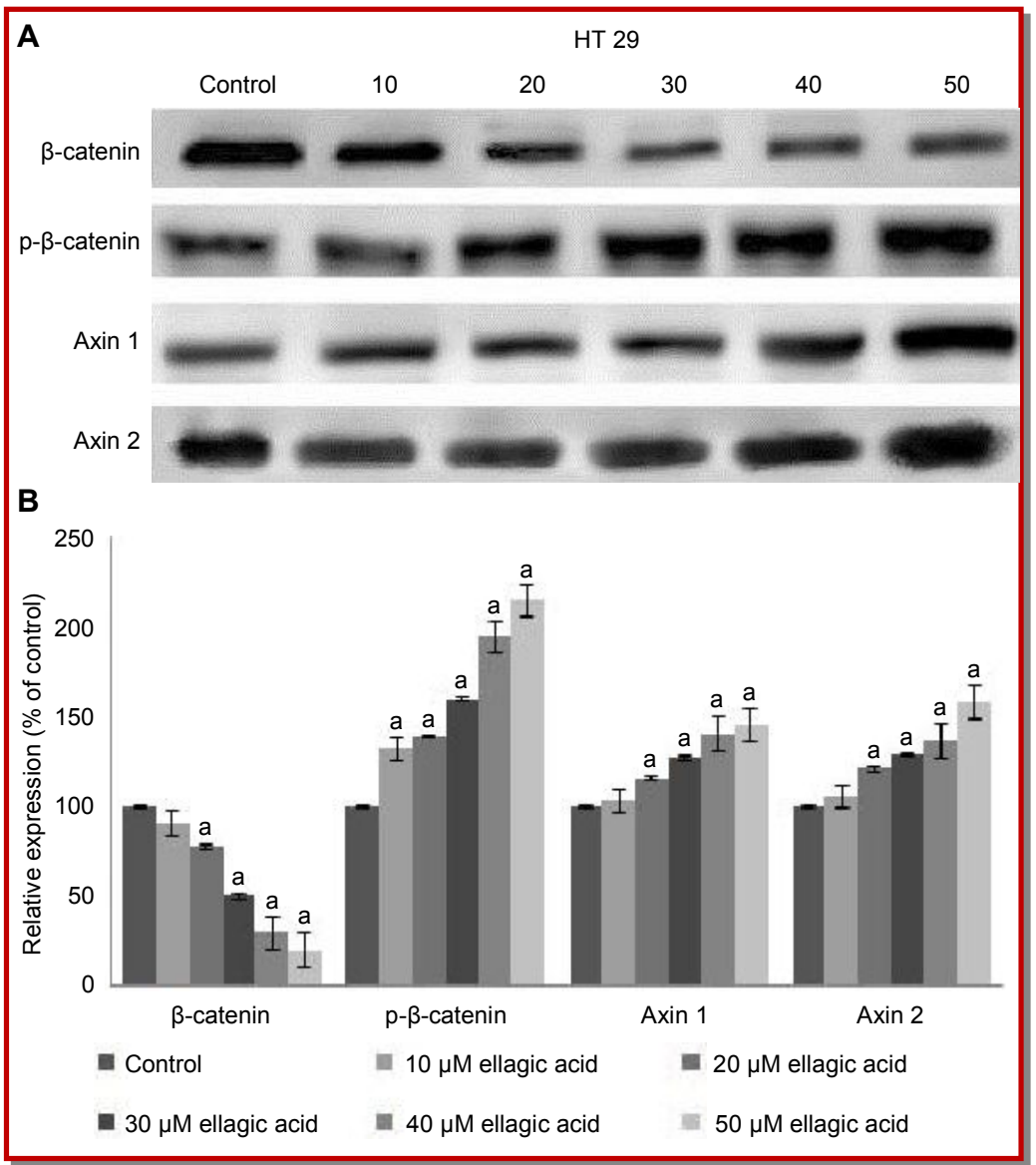

Figure 2: Influence of ellagic acid on the expression of $\mathrm{Wnt} / \beta$-catenin signaling pathway proteins

Expression of Wnt/ $\beta$-catenin signaling pathway proteins in (A) HT 29 and (B) HCT 116 cells treated with ellagic acid (10-50 $\mu$ M). Relative expression of Wnt/ $\beta$-catenin signaling pathway proteins in (C) HT 29 and (D) HCT 116 cells. Values are represented as mean \pm SD, $\mathrm{n}=3$. ${ }^{\text {arepresents statistical }}$ significance at $\mathrm{p}<0.05$ compared against control as determined by one-way ANOVA

Wnt/ $\beta$-catenin signalling pathway, resulting in transactivation of cell proliferation, the expression levels of $\beta$ -catenin was assessed. Western blot analysis showed a remarkable decrease in the expression of $\beta$-catenin (Figure 2A and B). Since phosphorylation is known to regulate $\beta$-catenin degradation, we also investigated the 


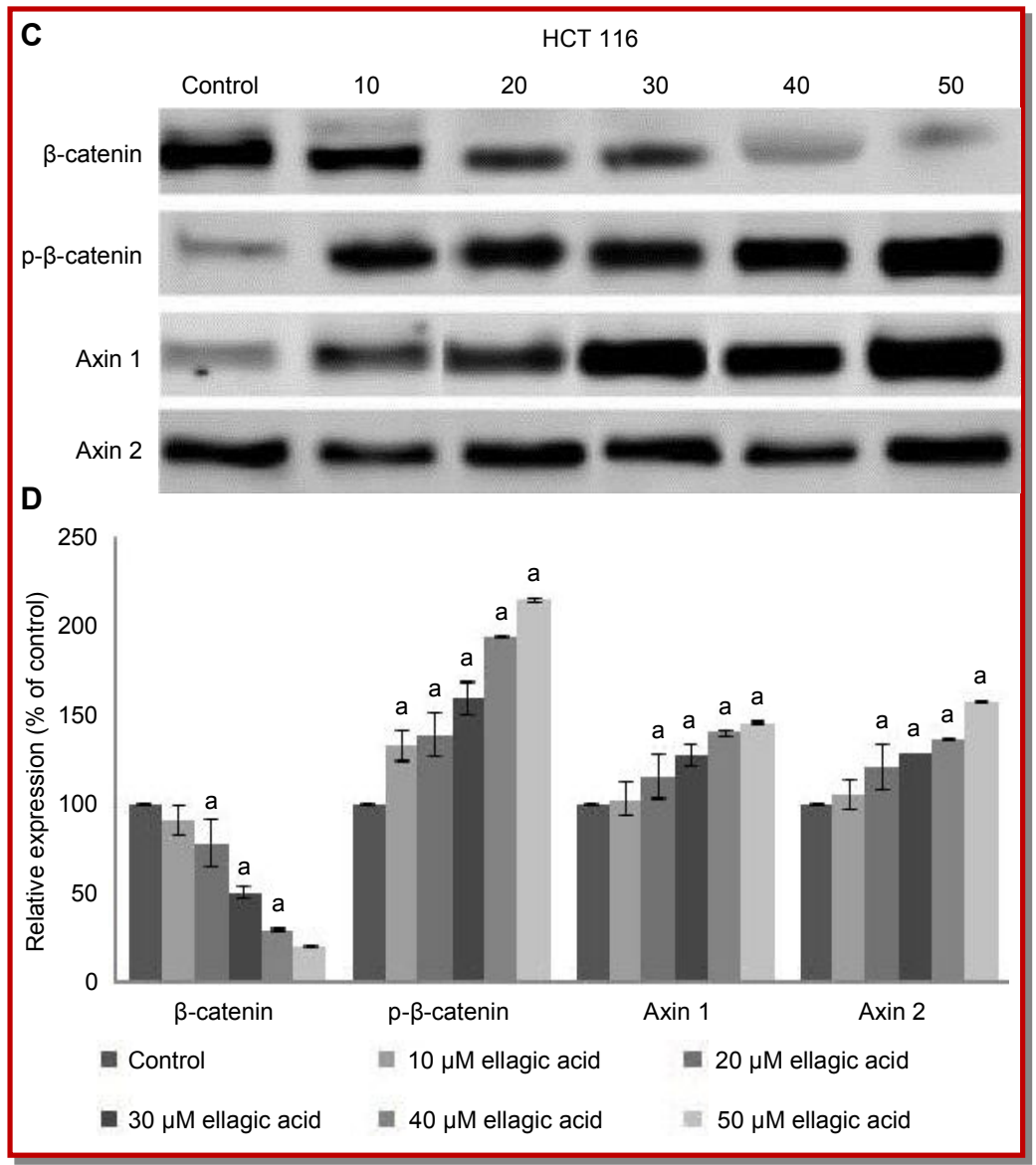

Figure 2: Influence of ellagic acid on the expression of Wnt/ $\beta$-catenin signaling pathway proteins (Cont.)

expression of phosphorylated $\beta$-catenin. The expression of $p$ - $\beta$-catenin was observed to be increased in both HCT116 and HT 29 cells upon treatment with ellagic acid (10-50 $\mu \mathrm{M})$. The expression levels of axin1 and 2 in HT55 and HCT 116 cells were up-regulated following exposure to ellagic acid (Figure 2C and D). However, the increase in axin expressions was not as high as $p-\beta$ catenin.

Upon activation of Wnt signal, $\beta$-catenin travels into nucleus where it binds the TCF/Lef family of transcription factors, and actives the transcription of downstream target genes. To assess the effect of ellagic acid on TCF/Lef regulation, the protein expressions of known TCF targeted genes, such as c-Myc, survivin and cyclin D1 were determined. The data showed remarkable decrease of the proteins on exposure to ellagic acid in a dose-dependent manner compared to the expression in colon cancer cells not exposed to ellagic acid (Figure 3A-D).

CDK8 has been reported to promote the proliferation of colorectal cancer cells through stimulating $\beta$-cateninmediated transcription. The effect of ellagic acid on CDK8 expression was studied. Ellagic acid at $50 \mu \mathrm{M}$ caused a slight decrease in the levels of CDK8 (Figure 4 ), lower concentrations of ellagic acid, however had not much effect on regulating the expression of CDK8.

To further investigate the role of CDK8 in $\beta$-catenin/ TCF transcription, CDK8 expression in HCT116 and HT 29 cells were silenced by RNA interference. The expression of survivin, cyclinD1 and c-Myc were detected by western blotting. In CDK8 siRNA-transfected cells a decrease in the expressions of c-Myc, survivin and cyclin D1 was observed and similar data were obtained in ellagic acid $(50 \mu \mathrm{M})$ treated cells (Figure 5A-C).

\section{Discussion}

Colon cancer is one of most frequent and best-studied malignancies. Despite recent advances in chemotherapies that have improved survival rate of patients, patients with late-stage disease still have poor prognosis, with the overall mortality being around 40\% (Luo et al., 2014). It has been reported that several signal pathways, including $\mathrm{Wnt} / \beta$-catenin play critical roles in its pathogenesis (Chen and Huang, 2009).

The Wnt signaling cascade plays various roles in stem cell maintenance, cell proliferation, differentiation, and apoptosis (Guo et al., 2014; Xing et al., 2014). Deregulation of Wnt/ $\beta$-catenin signaling is a hallmark of the majority of sporadic forms of colorectal cancer and 




Figure 3: Effect of ellagic acid on the expression of $\beta$-catenin/TCF target proteins

Expression of $\beta$-catenin/TCF target proteins in (A) HT 29 cells and (B) HCT 116 cells treated with ellagic acid (10 -50 $\mu \mathrm{M})$. Relative expression of $\beta$ -

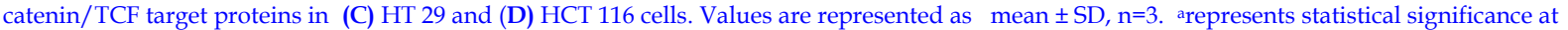
$\mathrm{p}<0.05$ compared against control as determined by one-way ANOVA

results in increased stability of the protein $\beta$-catenin (Herbst et al., 2014).

Dietary phytochemicals have conventionally been used as a health food for the prevention and therapy of cancer (Jaramillo et al., 2010). The inhibitory effects against cancer cells by phytochemicals have been suggested to be mediated by various mechanisms of action such as i) regulation of the expressions of oncogenes and tumor suppressor genes, ii) modulation or inhibition of signal transduction pathways involving MAPK, Nrf and AP-1, and iii) induction of cell-cycle arrest and apoptosis involving the p53, Bcl-2 and caspase families (Avila et al., 1994; Sarkar et al, 2009; Gadgeel et al., 2009; Jaramillo et al., 2010; Kim et al., 2010; Deep and Agarwal 2010). In recent years, much progress has been made on understanding $\mathrm{Wnt} / \beta$-catenin signaling in respect to cancer development and their possible modulators, which could be useful in cancer prevention and therapy. Identification of compounds that specifically target Wnt signaling pathway thus is considered to be potential for treating colorectal cancers. In this regard, small molecules like flavonoids synthesized or from natural origin, have been identified as potential modulators of Wnt/ $\beta$-catenin signaling pathway (Sarkar et al., 2009; Thorne et al., 2010).

In the study, ellagic acid was found to effectively decrease the cell viability of HT 29 and HCT 116 colon cancer cells. The cell viability percentage was found to decrease multifolds with increase in concentration of ellagic acid, indicating the anti-proliferative capacity.

Since $W n t / \beta$-catenin signaling plays a critical role in the regulation of colon tissue regeneration and the development of colon cancer (Schon et al., 2014), the expression of $\mathrm{Wnt} / \beta$-catenin signaling proteins were assessed after exposure to ellagic acid. The expression of $\beta$-catenin was decreased significantly in HT29 and in HCT 116 cells treated with ellagic acid, however a marked increase in the expression of $\mathrm{p}$ - $\beta$-catenin levels was observed.

Under physiological conditions, $\beta$-catenin activity is tightly controlled. When Wnt signal is initiated and the pathway is cascaded, this causes $\beta$-catenin to shuttle into the nucleus where it activates the transcription of 


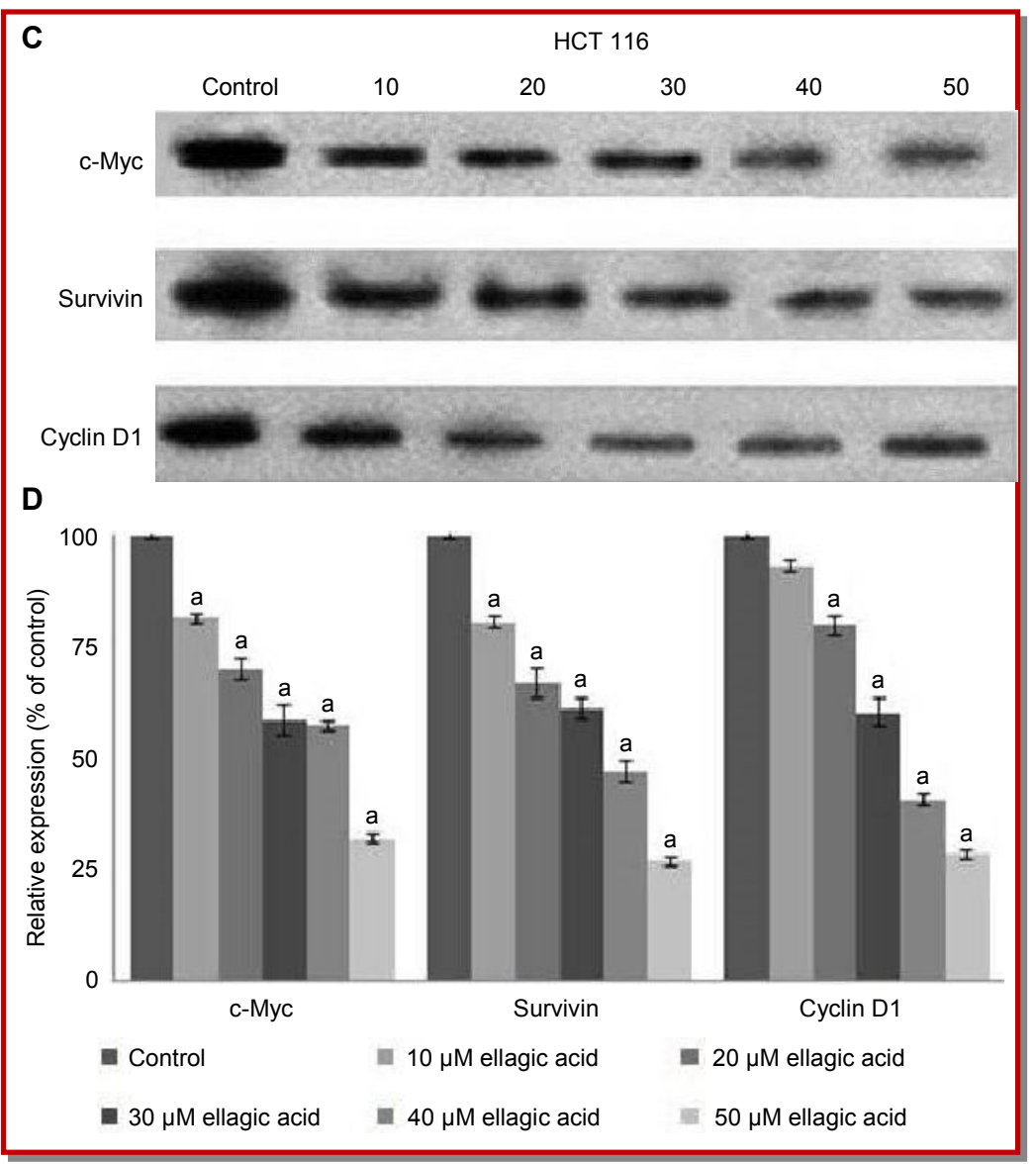

Figure 3: Effect of ellagic acid on the expression of $\beta$-catenin/TCF target proteins (Cont.)

its target genes (Li et al., 2014).

The level of $\beta$-catenin in the cells is regulated by $\beta$ catenin phosphorylation and degradation by the APC complex (Klaus and Birchmeier, 2008). In most colon cancers, the $\beta$-catenin degradation system becomes abnormal, resulting in constant expression of $\beta$-catenin and resultant activation of downstream genes.

The observed decrease in $\beta$-catenin levels and increase in $p$ - $\beta$-catenin expression suggests that ellagic acid effectively inactivated $\beta$-catenin and promoted its degradation and thereby modulating Wnt/ $\beta$-catenin signalling cascade. This is further supported by the expression levels of axins. Western blot analysis showed that the protein level of axin1 and 2, one of the main components of destruction complex was increased on exposure to ellagic acid.

Further the results of protein expressions of known TCF targeted genes such as c-Myc, survivin and cyclin D1 in HT 29 and HCT 116 cells exposed to ellagic acid were down regulated significantly with increase in concentration is suggestive of effective down regulation of Wnt $\beta$ catenin cascade. CDK8, known as transcriptional CDKs, is a nuclear serine-threonine kinase that is reported to be involved in regulating $\beta$-catenin
(Firestein et al., 2008; Galbraith et al., 2010).

In the present study, ellagic acid significantly downregulates the expression of CDK8 in a concentration dependent manner. The results suggest that this also could be a possible reason for the decrease in levels of $\beta$ -catenin as observed in HT 29 and HCT 116 cells exposed to ellagic acid.

It has been previously reported that CDK8 affect the transcription activities of $\beta$-catenin through two possible ways. Firstly, CDK8 could possibly activate $\beta$ catenin-mediated transcription as part of the CDKmodule. The $\beta$-catenin transactivation domain interacts with MED12 (Mediator of RNA polymerase II transcription, subunit 12 homolog) via its C-terminal domain in mammalian cells and is able to recruit mediator to $\beta$ catenin/TCF target genes in vivo (Kim et al., 2006). Another possible mechanism is that CDK8 directly phosphorylates E2F1 (Zhao et al., 2013). This phosphorylation by CDK8 decreases the ability of E2F1 to repress transcription of $\beta$-catenin/TCF-dependent genes, such as c-Myc, PPARY and CD44 (Morris et al., 2008), or by up-regulating the expression of proteins that mediate $\beta$-catenin degradation, such as AXIN1/2 (Hughes and Brady, 2005; Wu et al., 2011). 


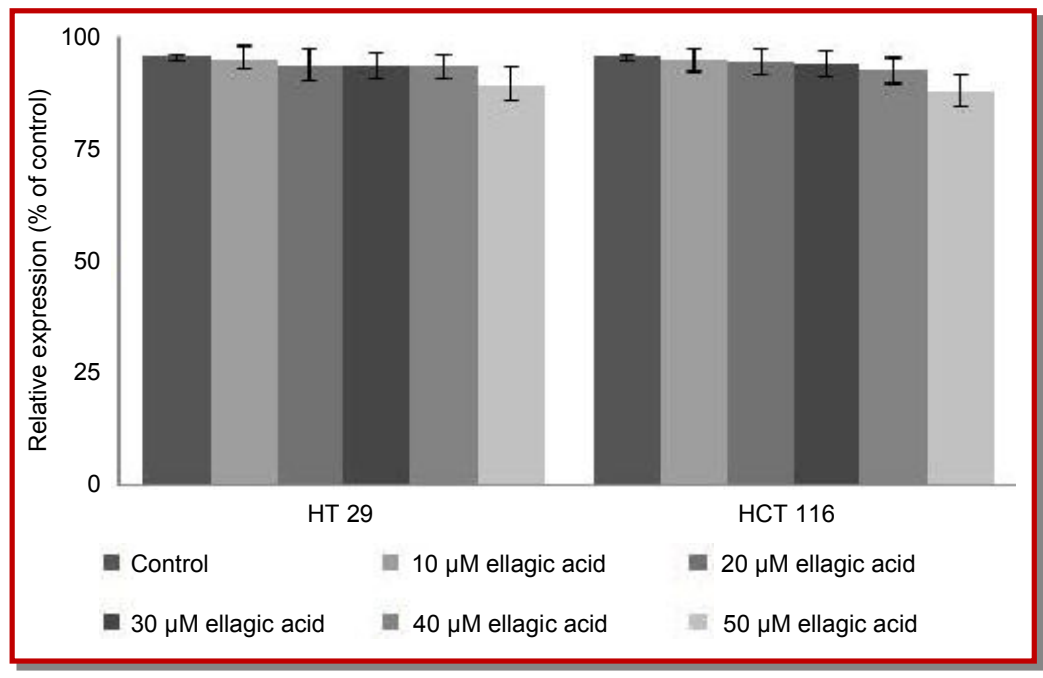

Figure 4: Effect of ellagic acid on CDK8 expression in colon cancer cells

Values are represented as mean $\pm S D ; n=3$

The transfection with siCDK8 resulted in a marked decrease in the expression of c-Myc, survivin and cyclin D1 in the colon cancer cells. This is in line with the previous findings that CDK8 stimulates $\beta$-cateninmediated transcription. The expression levels of the cMyc, survivin and cyclin D1 in cells transfected with siCDK8 was similar to the levels in cells treated with 50 $\mu \mathrm{M}$ ellagic acid. The observed decrease in expression on incubation with ellagic acid indicates that the compound was able to efficiently either inactivate CDK8 and/or suppress the expression of CDK8.

To summarize, ellagic acid was found to efficiently inhibit the cell viability of colon cancer cells (HT29 and HCT 116) and down regulate the expression of $\beta$ catenin and increase the degradation of $\beta$-catenin by raising the levels of $p-\beta$-catenin and axin 1 and 2 . The suppression of CDK8, c-Myc, survivin and cyclin D1 expressions in the colon cancer cells on treatment with ellagic acid suggests the effectiveness of the compound in therapy of colon cancer.

Our observations indicate efficient anti-proliferative activity, regulation of $\beta$-catenin signaling and modulation of CDK8 activity by ellagic acid suggesting the possibilities for exploitation in colon cancer therapy.

\section{References}

Avila MA, Velasco JA, Cansado J, Notario V. Quercetin mediates the down-regulation of mutant p53 in the human breast cancer cell line MDAMB468. Cancer Res. 1994; 54: 2424-28.

Bharati R, Jenkins MA, Lindor NM, Le Marchand L, Gallinger S, Haile RW, Newcomb PA, Hopper JL, Win AK. Does risk of endometrial cancer for women without a germline mutation in a DNA mismatch repair gene depend on family history of endometrial cancer or colorectal cancer? Gynecol
Oncol. 2014; 133: 287-92.

Chen J, Huang XF. The signal pathways in azoxymethaneinduced colon cancer and preventive implications. Cancer Biol Ther. 2009; 8: 1313-17.

Clevers H. Wnt/beta-catenin signaling in development and disease. Cell 2006; 127: 469-80.

Conaway RC, Sato S, Tomomori-Sato C, Yao T, Conaway JW. The mammalian Mediator complex and its role in transcriptional regulation. Trends Biochem Sci. 2005; 30: 250 -55 .

Damaschke NA, Yang B, Bhusari S, Svaren JP, Jarrard DF. Epigenetic susceptibility factors for prostate cancer with aging. Prostate 2013; 73: 1721-30.

Davies RJ, Miller R, Coleman N. Colorectal cancer screening: Prospects for molecular stool analysis. Nat Rev Cancer. 2005; 5: 199-209.

Deep G, Agarwal R. Antimetastatic efficacy of silibinin: molecular mechanisms and therapeutic potential against cancer. Cancer Metastasis Rev. 2010; 29: 447-63.

Donner AJ, Szostek S, Hoover JM, Espinosa JM. CDK8 is a stimulus-specific positive coregulator of p53 target genes. Mol Cell. 2007; 27: 121-33.

Espada J, Calvo MB, Diaz-Prado S, Medina V. Wnt signalling and cancerstem cells. Clin Transl Oncol. 2009; 11: 411-27.

Firestein R, Bass AJ, Kim SY, Dunn IF, Silver SJ, Guney I, Freed E, Ligon AH, Vena N, Ogino S, Chheda MG, Tamayo P, Finn S, Shrestha Y, Boehm JS, Jain S, Bojarski E, Mermel C, Barretina J, Chan JA, Baselga J, Tabernero J, Root DE, Fuchs CS, Loda M, Shivdasani RA, Meyerson M, Hahn WC. CDK8 is a colorectal cancer oncogene that regulates beta-catenin activity. Nature 2008; 455: 547-51.

Fryer CJ, White JB, Jones KA. Mastermind recruits CycC:CDK8 to phosphorylate the Notch ICD and coordinate activation with turnover. Mol Cell. 2004; 16: 509-20.

Gadgeel SM, Ali S, Philip PA, Wozniak A, Sarkar FH. 


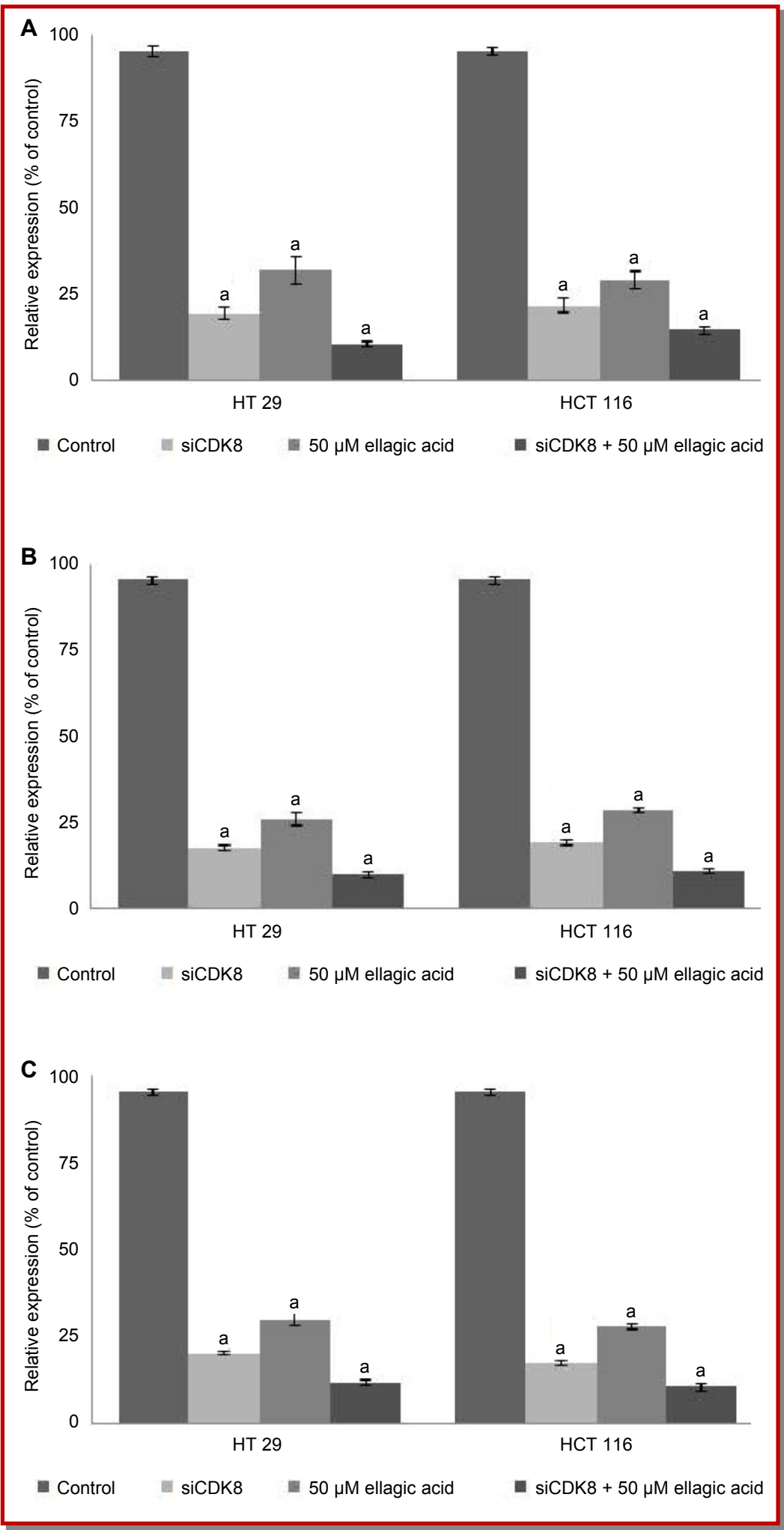

Figure 5: Influence of ellagic acid and siCDK8 on (A) c-Myc, (B) Survivin, (C) cyclin D1 expression in colon cancer cells Values are represented as mean $\pm \mathrm{SD} ; \mathrm{n}=3$; arepresents $\mathrm{p}<0.05$ compared with control as determined by one-way ANOVA

Genistein enhances the effect of epidermal growth factor receptor tyrosine kinase inhibitors and inhibits nuclear factor kappa B in nonsmall cell lung cancer cell lines. Cancer 2009; 115: 2165-76. 
Galbraith MD, Donner AJ, Espinosa JM. CDK8: A positive regulator of transcription. Transcription 2010; 1: 4-12.

Guo D, Li Q, Lv Q, Wei Q, Cao S, Gu J. MiR-27a targets sFRP1 in hFOB cells to regulate proliferation, apoptosis and differentiation. PLoS ONE. 2014; 9: e91354.

Herbst A, Jurinovic V, Krebs S, Thieme SE, Blum H, Goke B, Kolligs FT. Comprehensive analysis of beta-catenin target genes in colorectal carcinoma cell lines with deregulated Wnt/ beta-catenin signaling. BMC Genomics. 2014; 15: 74.

Hughes TA, Brady HJ. Cross-talk between pRb/E2F and Wnt/ beta catenin pathways: E2F1 induces axin2 leading to repression of Wnt signalling and toincreased cell death. Exp Cell Res. 2005; 303: 32-46.

Jaramillo S, Lopez S, Varela LM, Rodriguez-Arcos R, Jimenez A, Abia R, Guillen RG, Muriana FJ. The flavonol isorhamnetin exhibits cytotoxic effects on human colon cancer cells. J Agric Food Chem. 2010; 58: 10869-75.

Kim S, Xu X, Hecht A, Boyer TG. Mediator is a transducer of Wnt/beta-catenin signaling. J Biol Chem. 2006; 281: 1406675.

Kim HJ, Kim SK, Kim BS, Lee SH, Park YS, Park BK, Kim SJ, Kim J, Choi C, Kim JS, Cho SD, Jung JW, Roh KH, Kang KS, Jung JY. Apoptotic effect of quercetin on HT-29 colon cancer cells via the AMPK signaling pathway. J Agric Food Chem. 2010; 58: 86430-50.

Kim JH, Kim YH, Song GY, Kim DE, Jeong YJ, Liu KH, et al., Ursolic acid and its natural derivative corosolic acid suppress the proliferation of APC-mutated colon cancer cells through promotion of beta-catenin degradation. Food Chem Toxicol. 2014; 67: 87-95.

Klaus A, Birchmeier W. Wnt signalling and its impact on development and cancer. Nat Rev Cancer. 2008; 8: 387-98.

Larrosa M, Tomas-Barberan FA, Espin JC. The dietary hydrolysable tannin punicalagin releases ellagic acid that induces apoptosis in human colon adenocarcinoma Caco-2 cells by using the mitochondrial pathway. J Nutr Biochem. 2006; 17: 611-25.

Li H, Lee HJ, Ahn YH, Kwon HJ, Jang CY, Kim WY, Ryu JH. Tussilagone suppresses colon cancer cell proliferation by promoting the degradation of beta-catenin. Biochem Biophys Res Commun. 2014; 443: 132-37.

Luo Y, Wong CJ, Kaz AM, Dzieciatkowski S, Carter KT, Morris SM, Wang J, Willis JE, Makar KW, Ulrich CM, Lutterbaugh JD, Shrubsole MJ, Zheng W, Markowitz SD, Grady WM. Differences in DNA methylation signatures reveal multiple pathways of progression from adenoma to colorectal cancer. Gastroenterology 2014; 147: 418-29.

Miyaki M, Konishi M, Kikuchi-Yanoshita R, Enomoto M, Igari T, Tanaka K, Muraoka M, Takahashi H, Amada Y, Fukayama M, Maeda Y, Iwama T, Mishima Y, Mori T, Koike $\mathrm{M}$. Characteristics of somatic mutation of the adenomatous polyposis coli gene in colorectal tumours. Cancer Res. 1994; 54: 3011-20.

Morris EJ, Ji JY, Yang F, Di Stefano L, Herr A, Moon NS, Kwon EJ, Haigis KM, Naar AM, Dyson NJ. E2F1 represses betacatenin transcription and isantagonized by both $\mathrm{pRB}$ and CDK8. Nature 2008; 455: 552-56.
Mullen W, Yokota T, Lean ME, Crozier A. Analysis of ellagitannins and conjugates of ellagic acid and quercetin in raspberry fruits by LC-MS. Phytochemistry 2003; 64: 617-24.

Pan $\mathrm{MH}$, Lin $\mathrm{CL}$, Tsai JH, Ho CT, Chen WJ. 3,5,3', $4^{\prime}, 5^{\prime}-$ Pentamethoxystilbene (MR-5), a synthetically methoxylated analogue of resveratrol, inhibits growth and induces G1 cell cycle arrest of human breast carcinoma MCF-7 cells. J Agric Food Chem. 2010; 58: 226-34.

Reya T, Clevers $\mathrm{H}$. Wnt signalling in stem cells and cancer. Nature 2005; 434: 843-50.

Sarkar FH, Li Y, Wang Z, Kong D. Cellular signaling perturbation by natural products. Cell Signal. 2009; 21: 154147.

Schon S, Flierman I, Ofner A, Stahringer A, Holdt L, Kolligs FT, Herbst A. beta-catenin regulates NF-kappaB activity via TNFRSF19 in colorectal cancer cells. Int J Cancer. 2014; 135: 1800-11.

Stoner GD, Gupta A. Etiology and chemoprevention of esophageal squamous cell carcinoma. Carcinogenesis 2001; 22: $1737-46$

Talcott ST, Lee JH. Ellagic acid and flavonoid antioxidant content of muscadine wine and juice. J Agric Food Chem. 2002; 50: 3186-92.

Thorne CA, Hanson AJ, Schneider J, Tahinci E, Orton D, Cselenyi CS, Jernigan KK, Meyers KC, Hang BI, Waterson AG, Kim K, Melancon B, Ghidu VP, Sulikowski GA, LaFleur B, Salic A, Lee LA, Miller DM, Lee E. Small-molecule inhibition of Wnt signaling through activation of casein kinase 1a. Nat Chem Biol. 2010; 6: 829-36.

Thresiamma KC, Kuttan R. Inhibition of liver fibrosis by ellagic acid. Indian J Physiol Pharmacol. 1996; 40: 363-66.

Walker AS, Johnson EK, Maykel JA, Stojadinovic A, Nissan A, Brucher B, Champagne BJ, Steele SR. Future directions for the early detection of colorectal cancer recurrence. J Cancer. 2014; 5: 272-80.

Watson AJ. An overview of apoptosis and the prevention of colorectal cancer. Crit Rev Oncol Haematol. 2006; 57: 107-21.

Wu Z, Zheng S, Li Z, Tan J, Yu Q. E2F1 suppresses Wnt/betacatenin activity through transactivation of beta-catenin interacting protein ICAT. Oncogene 2011; 30: 3979-84.

Xing J, Cao G, Fu C. HMGA1 interacts with beta-catenin to positively regulate $\mathrm{Wnt} /$ beta-catenin signaling in colorectal cancer cells. Pathol Oncol Res. 2014; 20: 847-51.

Xu Y, Deng JZ, Ma J, Chen SN, Marshall R, Jones SH, Johnson RK, Hecht SM. DNA damaging activity of ellagic acid derivatives. Bioorg Med Chem. 2003; 11: 1593-96.

Zhang J, Cao H, Zhang B, Xu X, Ruan H, Yi T, Tan L, Qu R, Song $\mathrm{G}$, Wang $\mathrm{B}, \mathrm{Hu} \mathrm{T}$. Berberine potently attenuates intestinal polyps growth in ApcMin mice and familial adenomatous polyposis patients through inhibition of Wnt signalling. J Cell. Mol Med. 2013; 17: 1484-93.

Zhao J, Ramos R, Demma M. CDK8 regulates E2F1 transcriptional activity through S375 phosphorylation. Oncogene 2013; 32: 3520-30

Zheng P, Liu YX, Chen L, Liu XH, Xiao ZQ, Zhao L, Li GQ, 
Zhou J, Ding YQ, Li JM. Stathmin, a new target of PRL-3 identified by proteomic methods, plays a key role in progression and metastasis of colorectal cancer. J Proteome Res. 2010; 9: 4897-905.

Author Info

Yang Fang (Principal contact)

e-mail: fangyang6443@gmail.com

ᄂ - - - - - - - - - - - - - - - - - - - - - - - - - - - - - - - - - - - - - - - - - - - - - - - - - - - - - - - - - - 